\title{
OPTIONS FOR MULTIMODAL EXPRESSION, AND THE LITERACY REQUIRED FOR PERCEIVING THE MEANING OF TEXTUAL MATERIAL IN THE DIGITAL AGE
}

\author{
Larysa Makaruk \\ laryssa_makaruk@ukr.net \\ Lesya Ukrainka Eastern European National University, Ukraine
}

Received May, 28, 2016; Revised June, 15, 2016; Accepted June, 30, 2016

\begin{abstract}
This article deals with the visualization of textual information, and provides a description and an analysis of the principal means by which this process of visualization can be achieved. Extensive attention has been given to images of various kinds which are being employed nowadays in almost all types of discourse and on different language levels, and their specific advantages and disadvantages have been noted. Other media devices including charts, graphs and various types of diagrams have received some attention as well, although not to the same degree, and their importance and their unique characteristics have been described. The distinctive features of non-verbal means have been analyzed in the light of the developmental patterns which can be observed in recent decades. A great deal of attention has been focused on the fact that traditional paradigms are in the process of being reoriented in the 21 st century. As a result of this evolution, it is necessary to reconsider some paradigms which we may have assumed to be fixed permanently. On a broader level, the concepts of multimodal and visual literacy have been characterized in terms of the approaches which are proving to be appropriate for present-day linguistic study.
\end{abstract}

Keywords: multimodal literacy, non-verbal means of communication, multimodality, semiotic resources, paralinguistic devices.

Макарук Лариса. Засоби мультимодальної експресії та необхідні навички грамотності для декодування значення тексту у цифровому столітті.

Анотація. У статті розглянуто способи візуалізації текстової інформації. Обгрунтовано особливості зображень, світлин, таблиць, діаграм, графіків. Значну увагу звернуто на ілюстративні компоненти та доцільність їх використання у різних типах дискурсу. Проаналізовано їх переваги та недоліки, беручи до уваги сучасні лінгвістичні парадигми. Окреслено специфіку паралінгвальних компонентів комунікації 3 урахуванням пріоритетних тенденцій розвитку соціуму. Зосереджено увагу на тому, що в XXI ст. відбулася переорієнтація традиційних парадигм як результат, виникла закономірна потреба у переосмисленні усталених підходів до аналізу текстів. Висвітлено поняття мультимодальна грамотність та візуальна грамотність 3 огляду на концепцію розвитку сучасного соціуму. Простежено взаємозв'язок і взаємозалежність кількох семіотичних ресурсів у межах одного тексту. Виявлено особливості вербальних та невербальних компонентів як складників різних знакових систем. Звернуто увагу на те, що характерною ознакою сучасної англомовної писемної комунікації $\epsilon$ симбіоз неоднорідних семіотичних ресурсів, які належать до кількох знакових систем. Обгрунтовано особливості невербальних одиниць, які, як і вербальні, можуть бути контекстуально залежними, часто вступають у парадигматичні зв'язки.

Ключові слова: мультимодальна грамотність, невербальні засоби комунікації, мультимодальність, семіотичні ресурси, паралінгвістичні засоби. 


\section{Introduction}

The texts with which ordinary people most often deal nowadays are multimodal, in the sense that they include both verbal and non-verbal devices, and with the passing of time, texts of this type are becoming more and more common. They demonstrate the creativity of the individuals who formulate texts of different styles and genres, and they also illustrate the wide range of spheres and new patterns that can be observed in in the world of modern communication.

From the point of view of linguistic analysis, it can be argued that it would be inappropriate to place these patterns and devices in the category of non-linguistic means. Some researchers have gone so far as to question the value of studying communicative material or devices which are beyond the range of verbal expression, but modern scholarly investigation has convincingly brought these phenomena into the realm of effective vehicles for conveying concepts and emotions. It is evident that the type of discourse within which these devices occur will inevitably influence the way in which an audience is likely to evaluate the effectiveness of the various kinds of units.

Individuals in the present era, like those of many generations before them, have to process some information that is verbal in form, and at other times they receive input which is of a non-verbal nature. Our particular focus is on the latter type of communicative 'material', represented in one or another type of graphic medium. From the physical standpoint, this material possesses a wide variety of different characteristics in the areas of form, appearance, size, structure, and function. From the theoretical point of view, it is important to consider the fact that they belong to diverse semiotic systems.

\section{Methods}

In the course of the research, descriptive, contextual, and distributional methods have been used, as well the processes of analysis and synthesis.

\section{The study}

Among the scholars who deal with issues related to multimodality the following names should be mentioned: S. Barnes (Barnes 2011), A. Berger (Berger 2008), J. Bateman (Bateman 2014), B. Bergstrom (Bergstrom 2008), G. Kress (Kress 2001; 2004; 2006; 2010), T. Leeuwen (Leeuwen 2001; 2006), P. Lester (Lester 2006), and K. O'Halloran (2011). Still, there are many questions for which we have no answers in this field of multimodality. The aim of this research is to analyze the peculiarities of some of the non-verbal means which are employed in modern communication and to devote attention to multimodal literacy, which needs to be recognized as a vital skill for deriving meaning and information from the material to which individuals in the modern world are exposed.

Among the non-verbal elements which are used in modern multimodal discourse we identified five groups (some of which include subgroups): segmentation and other graphic effects, font and color, non-pictorial and nonphotographic graphic textual elements, iconic language elements (images) and other 
non-verbal means. In the course of this present research project we have devoted attention primarily to the categories of non-verbal means involving images, photos, tables, maps, charts, graphs, and diagrams. Other areas of multimodality mentioned above have been touched on at some length in previous studies, and will be the centre of attention in another paper that will be presented in the relatively near future.

An important point to consider is that although the text and the images that accompany it are often considered as a single entity, the text and the illustrations actually perform functions which are very distinct from one another. Texts generally consist of a step-by-step, detailed presentation of the content which the author wishes to convey to his readers, and the images (such as photos) are intended to present some form of visual confirmation of the points that are discussed in the text.

\section{Results and discussion}

In the modern process of communication, images have not only become an integral part of the text, performing the function of completing and intensifying information, but in a sense can themselves become a part of the sentence or the word, replacing its components and/or performing a number of different functions. Images often replace individual syllables or letters, and increasingly, this is extending to whole words, serving the functions of verbs or nouns.

We have already indicated that images are intended to facilitate the transmission of information, but at the same time we must recognize the fact that they sometimes actually complicate that process. They can have an effect on the coherence and cohesiveness of a text, which are inextricably linked with its effectiveness. When this aspect is taken into consideration, it becomes somewhat significant to devise some way of calculating the proportions of verbal and nonverbal information expressed in a text; however, to do this precisely in terms of percentages would be quite difficult, although it might be feasible with reference to one specific information unit. A casual observer might assume that the amount of space on the page that is occupied by graphic images provides a simple indicator of these proportions. However, it must be remembered that the physical size of the image or images is not the only important criterion: consideration must also be given to the volume of information conveyed by the image, the relative importance of that information within the text as a whole, and the degree to which the use of the image successfully achieves a specific desired result. Sometimes a successful combination of several well-chosen images belonging to different semiotic systems can be very effective in facilitating comprehensibility and perceptibility.

It is useful to bear in mind that graphic objects used in texts are not only of an informative nature: they are often used for other purposes, such as to entertain those who see them, or to convince people to purchase some item that is for sale or some type of service that is offered. Whatever the case may be, the process of perceiving information involves both verbal and nonverbal aspects, and in in most cases begins with a graphic component which is almost impossible to overlook when perusing the text. This impels the reader to read the text from start to finish, and during this 
process the non-verbal elements often convey information which, for one reason or another, may be unclear in the verbal part of the text. In other words, nonverbal components often serve to illustrate the most important aspects of the text as a whole, and to enhance the comprehensibility of any elements which could be difficult to grasp.

It must be noted that these combinations of words along with images functioning as words represent quite an original phenomenon, and one which demands certain corresponding skills on the part of the recipient. This can create a new problem: as many scholars have noted, the question arises whether people can actually be taught to 'read' images, considering the fact that they must put forth a certain amount of effort and possess certain types of background knowledge. Reading images is beyond the scope of that which can be defined in terms of specific rules, and reaches into the domain of contemplation and imagination, where there are no clear and fixed rules.

The process of becoming familiar with the elements of written and oral expression is one that begins in childhood, and over the course of a considerable period of time individuals gradually master the skills of reading and writing ordinary verbal signs. This raises a question to be considered: if learners come to realize how significant this aspect is, will they then be motivated to master the specific literacy skills needed for extracting the essential information as they read messages that are partially or completely graphic in nature? The areas of study implicated in this question are completely new and are still in the process of evolving; many people don't even think about the specific process of deriving information from images, or even more, of becoming skilful in accomplishing this. As a matter of fact, this is undertaking is not as simple as it might seem to be at first glance.

One of the problems that considerably complicates the issue outlined above is the rapid and large-scale emergence and development of devices and technologies which have given and/or are giving rise to different, previously unknown methods of communication, and this process is irreversible. It is clear that realistically it would be impossible to create a dictionary of images in which a single illustration would be given a single unified value, or a restricted value; in fact, it would be futile even to attempt such a thing. It is necessary to recognize that we are not dealing with specific-sign systems, such as on road signs, in which one image has a single value; in cases of that kind, the process of interpretation is much simpler. However, changes may occur even in systems of this type, so they cannot be described as totally stable or unchangeable.

To a great extent, single images are the ones can be expected to be contextually dependent, and texts involving this feature are attracting an increasing amount of interest on the part of linguists. However, as we are not solely dependent upon the context, one single image can be deciphered in various ways using different words. Everything depends on the recipient and his vision of the world.

In a somewhat different category, and arguably much easier to deal with, are images which are an integral part of a word or sentence. In cases of this kind, the 
expressive possibilities are not unlimited, due to the simple fact that the rules which govern the contextual distribution of elements in a sentence-letters, syllables or words-remain in effect when one or more of those elements is replaced by a graphic feature; this is the restrictive factor. It is also important to note that in cases of this kind, it is possible to break alphabetical letters down into the various straight or curved lines of which they are composed, and to replace these graphic elements with pictorial and symbolic elements which, in combination, are recognizable both in terms of the original letter and in terms of the concepts associated with the graphic forms.

Photos have particular value in situations where it is impossible for individuals to observe the real object, but it is naturally understood that the dimensional size of the photos does not correspond to reality which they represent. Primarily, photo images can be used to emphasize the importance of the key issues in the text, and may be utilized in place of a considerable body of verbal text that would otherwise be required to illustrate the facts or the events that are being presented.

Apart from photos, there are several other equally important ways of presenting textual information in a form that is more readily possible to visualize: among these are maps, and various types of charts and graphs. The latter are most often used when it is necessary to provide statistical information, and they are very suitable in such cases. They present information in the economic, political and sociological spheres, but their applicability is not limited to these fields: it is evident that there is no sector of industry where they cannot be utilized, and they are always available as an explicatory and illustrative instrument if such is required.

Tables constitute a means of presenting information in an orderly manner, and making it easier to assimilate. Like all other structures used for this purpose, they involve certain disadvantages, such as the smallness of the fonts which tend to be used, and the fact that vast amounts of data are shown in a single column or row. Their notable advantage is their effectiveness in enabling the user to make quick comparisons of information relative to a single specific issue.

Diagrams are used to provide a visual representation of something that we can imagine, but for which we have not found an appropriate vehicle of expression. They are very effective in illustrating situations, institutions or processes where a sequence of steps is involved, or where it is desirable to elucidate for an audience how various elements or steps are interrelated.

Charts, whether they be pie charts or those constructed with bars or lines, give a clear demonstration of statistical data, particularly when the object is to make the aspect of relative proportions immediately perceptible. It might be argued that in some cases they seem to add complexity to verbal information; hence it is advisable that they be used primarily in those cases where alternative methods cannot adequately present the data that is being transmitted.

Considering all the points that have been raised, it becomes evident that the first and the most important issue is to determine how all these semiotic resources (images, photos, tables, maps, charts, graphs, diagrams) are involved in the functioning of the communication. If they are involved in the communication 
process they should influence the meaning and have a part in the creation of meaning. These are only a few of the points to be considered in connection with the issue of multimodal literacy.

It should be mentioned that the non-verbal devices already referred to can be used in the mass media as well as in other spheres where written texts of any nature exist. However, the mass media environment is the one which I believe to be the most suitable for experimenting with the functioning of these elements. The majority of the non-verbal elements are present on the Internet (in blogs, chats, in Skype communication, in forums, in emails, and in other online sites) where communication is becoming considerably simplified, due to the fact that in many cases nothing needs to be typed: the very fact of clicking on some object can become an expression of a negative or positive opinion. Special combinations of keys can also be used to convey one's attitude towards something.

Some issues which have been touched on by C. Leborg (Leborg 2006), G. Kress and T. Van Leeuwen (Kress and Leeuwen 2006), as well as by J. Elkins (Elkins 2008), but on which I wish to focus more in-depth attention in the future, include the formulation of grammar rules for multimodal texts, the perception and recognition of multimodal texts and metaphors, and the overall issue of multimodal literacy.

Kress states that "we can no longer treat literacy (or 'language') as the sole, the main, let alone the major means for representation and communication. Other modes are there as well, and in many environments where writing occurs these other modes may be more prominent and more significant. As a consequence, a linguistic theory cannot provide a full account of what literacy does or is; language alone cannot give us access to the meaning of the multimodally constituted message; language and literacy now have to be seen as partial bearers of meaning only" (Kress 2004: 35).

It can definitely be affirmed that in any case, the process of multimodal communication demands that people acquire at least some basic skills in order to keep up with their contemporaries, and not be left behind. It is rather ironic that modern society, which has achieved such visible advances in many spheres of human life, has gradually and unwittingly returned to a means of communication which is closer to that which people employed at the dawn of history. It is clear that modern graphic illustrations are dramatically different from the ancient ones, but the essential content remains the same.

Donis A. Dondis (Dondis 1998) mentions that "language is a means of expression and communication and therefore, is parallel system to visual communication. We cannot slavishly copy the methods that are used to teach reading and writing, but we can observe and acknowledge them" (Dondis 1998: 182). Taking into account the fact that there are various kinds of paralinguistic signs, some language methods can be applied, such as for analysing the sentence "I $\checkmark$ it." The word order of this sentence doesn't differ from that which is natural in the language. Another question arises, in connection with morphological peculiarities, regarding the means of deciding whether a particular pictogram may be deciphered 
as corresponding to the present, past or future tenses-a distinction which can be readily recognized in verbal texts. This represents a real challenge.

\section{Conclusions}

Within the overall field of multimodality several aspects remain important which have been the object of study with respect to traditional forms of textual expression: orthography (the graphic representation of a letter, a word, a phrase or a sentence); vocabulary; and grammar (syntactic combinability). The most unpredictable situation involves pictures, in which meaning can be unclear and the transfer from the non-verbal system to the verbal (interpretation) can be carried out in an unlimited number of ways. Another question which arises in the process of the analysis is the formulation of grammar rules: first of all, whether it is possible to create a set of definite rules, and if so, whether one set of rules can apply to all of the groups, and whether even subgroups may have criteria of their own.

Literacy in the media age presupposes having at least some basic skills for decoding the meaning and peculiarities of non-verbal elements which are a part of multimodal texts. Individuals living in contemporary society must be also aware of the fact that every paralinguistic element, be it a dot, a line or a pictogram, conveys some content and can be context-dependent.

The general thought that we need to take with us after reading through the material presented above is that information can be presented in a large variety of ways, and that images represent an increasingly important component of expressive content. We noted that these images involve a variety of different genres and styles, and can take the form of tables, diagrams, charts, photos, maps, and graphs, each of which has certain inherent advantages and disadvantages. We observed the fact that several of the above items can be interwoven within a single multimodal text. This doesn't automatically imply that the use of several modes at the same time makes the process of communication more complicated, or that the text is easier to comprehend as a result. Fundamental factors that are constantly at play involve the specific selection of devices used; the communicative power of those devices individually or in combination with one another; and the precise attributes of the individuals who are the recipients of the information, including their background knowledge and their personal world view. Every modus has functions and distinctive features which define its affordance or inaffordance in any given case. It has been a source of satisfaction and deep scientific interest to explore these elements and processes, and it provides genuine motivation to pursue various related but as yet unexplored avenues of research in the future.

There are several additional points which should be considered when dealing with multimodal texts: whether texts should be studied separately if they can function together; whether verbal or non-verbal elements are of greater importance; which elements should be predominant; whether one semiotic resource can be considered as being more important, such as a pictogram or a picture, by comparison with a group of sentences which are only verbally represented; whether there are any rules which influence the process of choosing them; and whether one 
non-verbal element can be more important than several non-verbal ones. The question as to whether there are any special rules of syntactic combinability which apply both to verbal and to non-verbal devices must be considered.

\section{References}

1. Barnes B. S. (2011). An Introduction to Visual Communication: from Cave Art to Second Life. New York: Peter Lang Publishing Inc.

2. Berger, A. A. (2008). Seeing is Believing. An Introduction to Visual Communication. USA: McGrawHill. Learning Solutions.

3. Bateman, J. A. (2014). Text and Image: a Critical Introduction to the Visual/Verbal Divine. London \& New York: Routledge.

4. Bergstrom, B. (2008). Essentials of Visual Communication. London: Laurence King Publishing Ltd.

5. Donis A. D. (1998). A Primer of Visual Literacy. Cambridge \& London: The MIT Press

6. Elkins, J. (2008). Visual literacy. London \& New York: Routledge.

7. Kress G., Leeuwen, T. van. (2001). Multimodal Discourse: The Modes and Media of Contemporary Communication. London: Arnold.

8. Kress, G. (2004). Literacy in the New Media Age. London \& New York: Routledge.

9. Kress, G. (2010). Multimodality: a Social Semiotic Approach to Contemporary Communication. London and New York: Routledge.

10. Kress, G., Leeuwen, T. van. (2006). Reading Images: The Grammar of Visual Design. London \& New York: Routledge.

11. Leborg, C. (2006). Visual Grammar. New York: Princeton Architectural Press.

12. Lester, P. (2006). Visual Communication: Images with Messages. Canada: Wadsworth Cengage Learning.

13. O’Halloran, K. (2011). Multimodal Discourse Analysis. London \& New York: Continuum. 